\title{
LAB-SCALE INVESTIGATIONS DURING COMBUSTION OF AGRICULTURAL RESIDUES AND SELECTED POLISH COALS
}

\author{
Włodzimierz K. Kordylewski ${ }^{*}$, Krzysztof J. Mościcki ${ }^{1}$, Karol J. Witkowski ${ }^{2}$ \\ ${ }^{1}$ Wrocław University of Technology, Faculty of Mechanical and Power Engineering, Wybrzeże \\ Wyspiańskiego 27, 50-370 Wrocław, Poland \\ ${ }^{2}$ EDF POLSKA Sp. z o.o., ul. Ciepłownicza 1, 31-587 Kraków, Poland
}

\begin{abstract}
Preliminary lab-scale investigations were conducted on slagging abatement in biomass-firing by fuel mixing. Three agriculture biomass fuels and olive cake were used in the experiments. Polish lignites and bituminous coals were examined as anti-sintering additives. The effects of chlorine release, potassium retention and ash sintering were examined by heating samples of biomass fuels and additives in the muffle oven and, next, firing them in the laboratory down-fired furnace at the temperature in the range of $800-1150^{\circ} \mathrm{C}$. The obtained slag samples were analysed on: chlorine and potassium content, sintering tendency and crystalline components. Among the examined coals lignite from Turów mine and bituminous coal from Bolesław Śmiały mine appeared to be the most effective in potassium retention in aluminosilicate and chlorine release from slag. Possibly the major factor of these coals which reduced ash sintering was relatively high content of kaolinite
\end{abstract}

Keywords: biomass, coal, ash, chlorine, slagging, chlorine

\section{INTRODUCTION}

The International Energy Agency (IEA) forecasts that the world net electricity generation is going to increase by $93 \%$ by 2040 and that coal-fired power generation will remain the main source of $\mathrm{CO}_{2}$, the major greenhouse gas. Utilisation of biomass in power plants is an important alternative to lower $\mathrm{CO}_{2}$ emissions and to make the energy supply less dependent on fossil fuels. In Poland in 2012 more than $6.8 \mathrm{TWh}$ of energy was produced by biomass-firing and co-firing in power and heat generating plants. Different kinds of biofuels are being used with steady increasing contribution of agricultural crop residues.

Large scale biomass-firing in boilers could be a source of serious problems. These include biomassinduced chlorine corrosion and intensive slagging of heat exchanging surfaces (Montgomery et al., 2002). These two are the most common reasons for standstill of boilers and unintended replacement of membrane wall's fragments and superheater tubes. These negative effects are most often caused by two elements that are usually present in herbaceous biomass, especially in agricultural residues, i.e. potassium and chlorine. However, despite two decades of biomass-firing experience and considerable knowledge not all problems have yet been resolved.

There are several remedial measures to minimise negative effects in biomass-firing boilers. Different types of protecting coatings are in use against chlorine corrosion of membrane walls (Uusitalo et al., 2002). Superheater tubes could be made with more corrosion-resistant steels or plated with alloys (e.g.

*Corresponding author, e-mail: wlodzimierz.kordylewski@pwr.wroc.p1 
Inconel) (Lee et al., 2007). Potassium chloride sulphuration in flue gas by injecting some sulphur compounds before the superheater section is an effective method of chlorine release from ash (Kassman et al., 2013). Aluminosilicates of the kaolinite group appeared to be effective in potassium retention (Hardy et al., 2013; Steenari et al., 2009). A promising approach to prevention of intensive slagging is fuel-mixing (Thesis et al., 2006). A reduction of flue gas temperature before the superheater section and decrease in steam temperature can produce positive effects (Frandsen and van Lith, 2009).

The objective of the present study was to examine slagging abatement and hazard of high-temperature deposit-induced corrosion reduction in biomass-firing by fuel mixing. Preliminary lab-scale investigations during combustion of three sorts of agriculture residues and olive cake with a controlled addition of selected Polish coals were performed. The basic criterion applied for preliminary selection of coals was kaolinite content. Chlorine release, potassium retention and ash sintering tendency due to the reactions of coal ash and $\mathrm{KCl}$ were examined. The investigations were conducted in two stages: in the first stage the preliminary survey of the coals' anti-sintering influence was examined on the basis of experiments made in the laboratory oven. In the second stage combustion experiments were conducted by firing biomass fuels with additives in a vertical down-fired furnace. It was demonstrated that an addition of the selected domestic coals could substantially decrease chlorine content in ash and reduce intensity of slagging.

\section{EXPERIMENTAL}

\subsection{Preliminary investigations}

To limit the number of examined additives during firing tests, labour procedure proposed by Steenari and Lindqvis (1998) was used in the preliminary investigations. Mixtures of potassium chloride $(\mathrm{KCl})$ and an additive were heated in ceramic dishes at the temperature of $800-1100^{\circ} \mathrm{C}$ in an electrically heated laboratory muffle oven (CZYLOK FCF 5 SM type) for half an hour. The chlorine loss and sintering degree of the collected slag samples were analysed.

The chlorine content in a slag sample $[\mathrm{Cl}]_{\text {meas }}$ was determined according to the Polish standard PN-ISO 9297: 1944 (Mohra's method) in the Institute of Environmental Protection Engineering of Wrockaw University of Technology. The measured value $[\mathrm{Cl}]_{\text {meas }}$ was compared with the calculated value $[\mathrm{Cl}]_{\mathrm{ref}}$ in the sample of $\mathrm{KCl}$ and an additive mixture to determine the effectiveness of chlorine removal from a slag sample $\eta_{\mathrm{Cl}}$ using the formula:

$$
\eta_{C l}=\left(1-[\mathrm{Cl}]_{\text {meas }} /[\mathrm{Cl}]_{\text {ref }}\right) \cdot 100 \%
$$

The chemical composition of ash was determined using the SEM/EDS (Scanning Electron Microscope SEM coupled with Energy Dispersive X-ray Spectrometer EDS) method in the Electrotechnics Institute of Wrocław. In the same Institute the crystallographic analysis of ash and slag samples was made applying the XRD (X-Ray Diffraction) method (Kordylewski and Mościcki, 2012).

The sintering degree $(S D)$ for the collected slag samples was assessed applying the four-degree scale through visual inspection and manual strength test (Fernandez Llorente et al., 2008; Steenari et al., 2009):

- 0 - non-sintered (ash breaks at a light touch),

- 1 - slightly sintered (ash particles hold together, but the structure is easy to break),

- 2 - sintered (sinter is breakable, but it is not easy to separate single ash particles),

- 3 - strongly sintered (not breakable by hand, sometimes molten). 


\subsection{Firing tests}

Combustion experiments were made using the laboratory down-fired furnace (DFF) (1), which consists of $2 \mathrm{~m}$ high vertical tube ( $80 \mathrm{~mm}$ inner diameter) (Fig. 1). The furnace tube was made of heat resistant alloy steel. The temperature of the furnace wall was stabilised electronically (3) at the range of 1100$1150^{\circ} \mathrm{C}$ applying electric heaters of the combined power $12 \mathrm{~kW}$ (Hardy, 2011).

The sampling point of flue gas analysis was at the bottom of the DFF. The FTIR gas analyser GASMET DX-4000 was used to measure flue gas composition (CO, $\mathrm{CO}_{2}, \mathrm{NO}, \mathrm{NO}_{2}, \mathrm{O}_{2}, \mathrm{SO}_{2}$ and $\left.\mathrm{HCl}\right)$. Additionally, oxygen content was measured in flue gas by GA-40 analyser in order to control the stoichiometry ratio at the level approx. 1.2. Fly ash was separated from flue gas in a cyclone (5).

Above the flue gas sampling port there was a port to the deposit probe (4) simulating a superheater tube. The probe was an air-cooled steel tube, $500 \mathrm{~mm}$ long and $22 \mathrm{~mm}$ in the external diameter (Hardy, 2011). The metal (surface) temperature of the probe's working part was electronically controlled at approx. $650^{\circ} \mathrm{C}$ (Fig. 1).

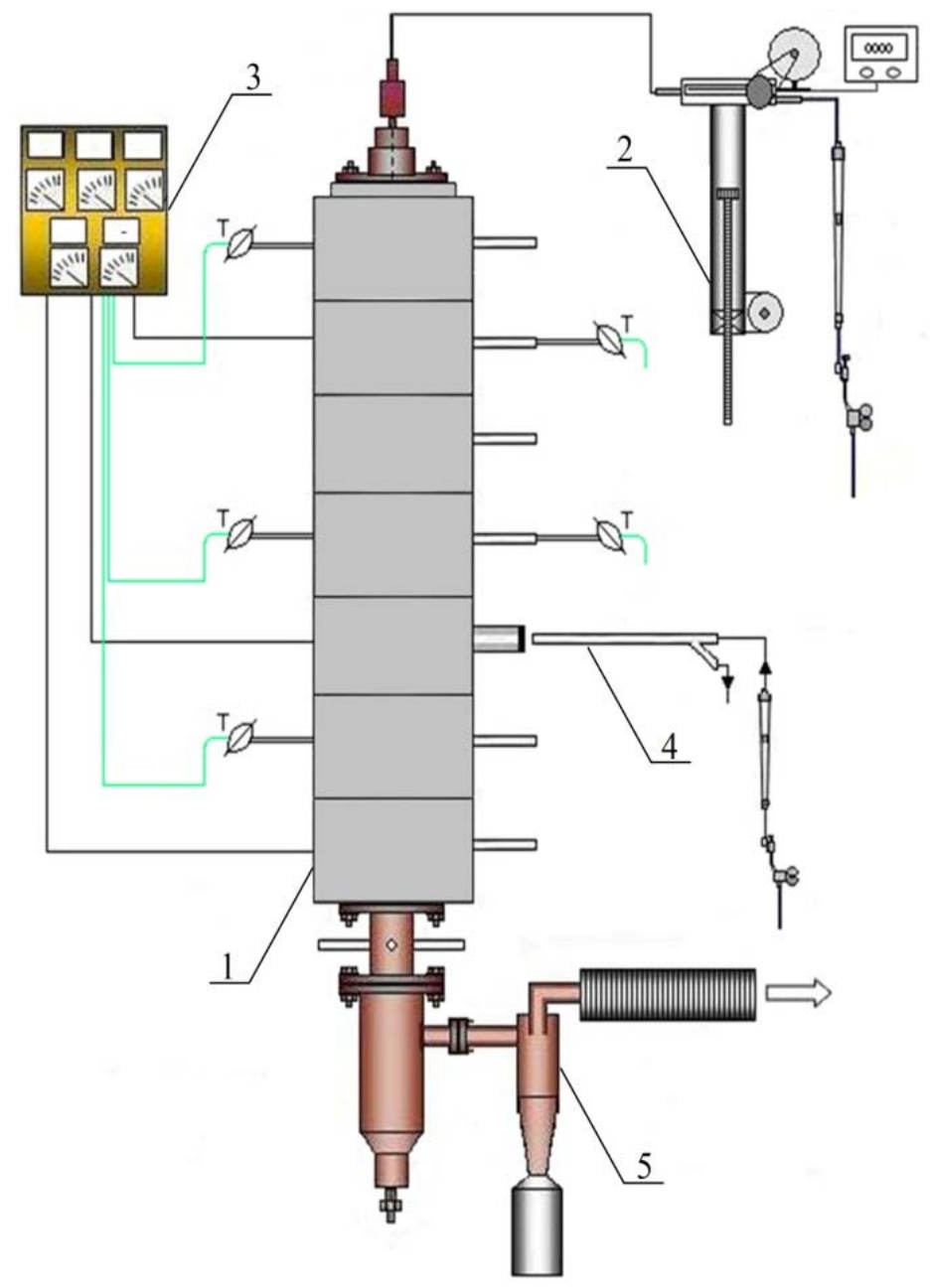

Fig. 1. Schematic drawing of the down-fired furnace, 1 - furnace, 2 - fuel feeder, 3 - control unit, 4 - deposit probe, 5 - cyclone

The grinded biomass fuel with an additive mixture was transported pneumatically by air from the feeder (2) into the DFF at the rate of 1-6 g/min. A single combustion experiment took between 20 to 40 minutes, depending on how fast the deposit was built on the deposit probe for a given biomass fuel. The sintering degree of the slag samples, their crystalline components and effectiveness of chlorine release, were examined applying the same methods as described in section 2.1. 


\section{BIOMASS, COAL AND ASH CHARACTERISTICS}

\subsection{Biomass}

Three representative agriculture residues: cereal straw, rape straw and sunflower husk, as well as imported biomass fuel, olive cake, were used in the experiments. The agriculture residues were obtained from different sources in the form of pellets. Before firing specified mixtures, biomass samples were dried, grinded and sieved on meshes in order to separate the 90-300 $\mu \mathrm{m}$ fraction for the combustion experiments. The selected parameters of proximate and ultimate analysis of biomass fuels are shown in Table 1.

Table 1. Proximate and ultimate analysis of used biomass fuels

\begin{tabular}{|c|c|c|c|c|}
\hline Parameter & Cereal straw & Sunflower husk & Rape straw & Olive cake \\
\hline $\mathrm{M}^{\text {ar }} \%$ mas. & 8.6 & 8.6 & 11.0 & 17.3 \\
\hline $\mathrm{V}^{\mathrm{d}}, \%$ mas. & 70.65 & 75.00 & 71.31 & 67.46 \\
\hline $\mathrm{A}^{\mathrm{d}}, \%$ mas. & 10.04 & 4.80 & 14.86 & 10.22 \\
\hline $\mathrm{S}^{\mathrm{d}}, \%$ mas. & 0.13 & 0.19 & 0.38 & 0.17 \\
\hline $\mathrm{Cl}^{\mathrm{d}}, \%$ mas. & 0.196 & 0.07 & 0.171 & 0.336 \\
\hline $\mathrm{LCV}^{\text {ar }}, \mathrm{MJ} / \mathrm{kg}$ & 14.54 & 18.42 & 13.87 & 14.55 \\
\hline
\end{tabular}

$\mathrm{d}-$ on dry basis, ar - on as received basis

Ash content in the cereal straw pellets, rape straw pellets and olive cake was more than average, which could result from biomass contamination.

The biomass fuels were ashed at the temperature of $600^{\circ} \mathrm{C}$ and the chemical composition of ash was determined using the ICP method by Energopomiar Gliwice (Poland). The silicon, calcium, magnesium and sodium content varied in a wide range, whereas the potassium content was on a comparatively high level for all the biomass (Tab. 2).

Table 2. Chemical composition of biomass ash, $\%$ mass

\begin{tabular}{|c|c|c|c|c|}
\hline Element & Cereal straw & Sunflower husk & Rape straw & Olive cake \\
\hline $\mathrm{SiO}_{2}$ & 52.10 & 9.52 & 22.10 & 15.10 \\
\hline $\mathrm{Al}_{2} \mathrm{O}_{3}$ & 1.15 & 1.07 & 1.73 & 2.28 \\
\hline $\mathrm{Fe}_{2} \mathrm{O}_{3}$ & 1.17 & 0.77 & 0.63 & 1.30 \\
\hline $\mathrm{TiO}_{2}$ & 0.07 & 0.07 & 0.15 & 0.14 \\
\hline $\mathrm{CaO}$ & 6.97 & 16.80 & 20.20 & 13.40 \\
\hline $\mathrm{MgO}$ & 1.85 & 10.40 & 1.24 & 4.26 \\
\hline $\mathrm{SO}_{3}$ & 1.81 & 5.20 & 8.49 & 2.49 \\
\hline $\mathrm{Na}_{2} \mathrm{O}$ & 0.34 & 0.25 & 0.33 & 4.41 \\
\hline $\mathrm{K}_{2} \mathrm{O}$ & 28.10 & 27.20 & 23.80 & 26.10 \\
\hline $\mathrm{Mn}_{3} \mathrm{O}_{4}$ & 0.13 & 0.05 & 0.08 & 0.05 \\
\hline $\mathrm{P}_{2} \mathrm{O}_{5}$ & 2.41 & 7.07 & 1.43 & 4.41 \\
\hline $\mathrm{BaO}$ & 0.05 & 0.02 & 0.05 & 0.02 \\
\hline $\mathrm{SrO}_{\mathrm{CO}}$ & 0.02 & 0.08 & 0.05 & 0.05 \\
\hline & 2.02 & 20.00 & 17.15 & 22.70 \\
\hline
\end{tabular}


Ash fusibility tests of the used biomass fuels were determined according to the Polish standard PN-G04535:1982 (Leitz's method) in the Central Mining Institute in Katowice. Cereal straw ash was most susceptible to sintering and sunflower husk ash was the most resistant to sintering (Tab. 3).

Table 3. Ash fusibility tests of the used biomass fuels (oxidising atmosphere)

\begin{tabular}{|l|c|c|c|c|}
\hline Characteristic temperature & Cereal straw & Sunflower husk & Rape straw & Olive cake \\
\hline sintering, ${ }^{\circ} \mathrm{C}$ & 860 & 1160 & 1150 & 1020 \\
\hline softening, ${ }^{\circ} \mathrm{C}$ & 1010 & 1350 & 1230 & 1240 \\
\hline melting, ${ }^{\circ} \mathrm{C}$ & 1060 & 1500 & 1270 & 1260 \\
\hline flowing, ${ }^{\circ} \mathrm{C}$ & 1170 & $>1500$ & 1300 & 1270 \\
\hline
\end{tabular}

\subsection{Coal}

The bituminous coals and lignite used in the investigations were delivered by Polish coal mines. The basic criterion for a coal to be selected as an additive was the kaolinite content. Unfortunately, the content of kaolinite in coal is not determined within the framework of standard coal analysis, therefore in the first approach nine coals of the mass ratio:

$$
\omega=\left[\mathrm{Al}_{2} \mathrm{O}_{3}\right] /\left[\mathrm{SiO}_{2}\right]
$$

close to kaolinite (0.85) were chosen from the Catalogue of Polish Bituminous Coals (2001). The choice of appropriate lignite was easier, because there are only three lignite mines in Poland (Bełchatów, Konin-Adamów and Turów). Lignite from the first two mines has a typical $\mathrm{C}$ ash of high calcium content (Chudek et al., 1999). Only lignite from Turów mine fulfilled the expectations, because its ash was similar to the hard coal ash (Tab. 4). Therefore, mainly lignite I and II from the Turów mine were used in these studies. They differed in the kaolinite content (Tab. 5).

Table 4. Chemical composition of coal ash ( $\%$ mass)

\begin{tabular}{|c|c|c|c|c|c|}
\hline Element & Bełchatów & Turów I & Turów II & $\begin{array}{c}\text { Bolesław } \\
\text { Śmiały }\end{array}$ & Wieczorek \\
\hline $\mathrm{SiO}_{2}$ & 15.31 & 42.58 & 52.78 & 48.01 & 49.63 \\
\hline $\mathrm{Al}_{2} \mathrm{O}_{3}$ & 12.33 & 36.66 & 28.29 & 33.03 & 16.93 \\
\hline $\mathrm{Fe}_{2} \mathrm{O}_{3}$ & 2.31 & 1.29 & 2.76 & 6.99 & 11.91 \\
\hline $\mathrm{TiO}_{2}$ & N/A & 1.29 & 3.37 & 1.12 & 0.78 \\
\hline $\mathrm{CaO}$ & 57.67 & 0.62 & 3.47 & 2.54 & 7.09 \\
\hline $\mathrm{MgO}$ & 3.64 & 0.25 & 1.92 & 2.27 & 4.84 \\
\hline $\mathrm{Na}_{2} \mathrm{O}$ & 0.48 & 0.98 & 3.25 & 0.56 & 1.27 \\
\hline $\mathrm{K}_{2} \mathrm{O}$ & 0.13 & 1.49 & 1.23 & 2.76 & 1.58 \\
\hline $\mathrm{Mn}_{3} \mathrm{O}_{4}$ & 0.04 & N/A & 0.03 & N/A & N/A \\
\hline $\mathrm{P}_{2} \mathrm{O}_{5}$ & N/A & N/A & N/A & 0.46 & 0.08 \\
\hline $\mathrm{BaO}^{\mathrm{SaO}}$ & 0.08 & N/A & N/A & N/A & N/A \\
\hline $\mathrm{SO}_{3}$ & 5.02 & N/A & N/A & N/A & N/A \\
\hline
\end{tabular}

N/A - not available

The chosen coals were subjected to phase analysis (XRD) in order to determine the approximate content of kaolinite (Fig. 2 and 3). The results of kaolinite determination for the selected coals and several ashes are shown in Table 5. 

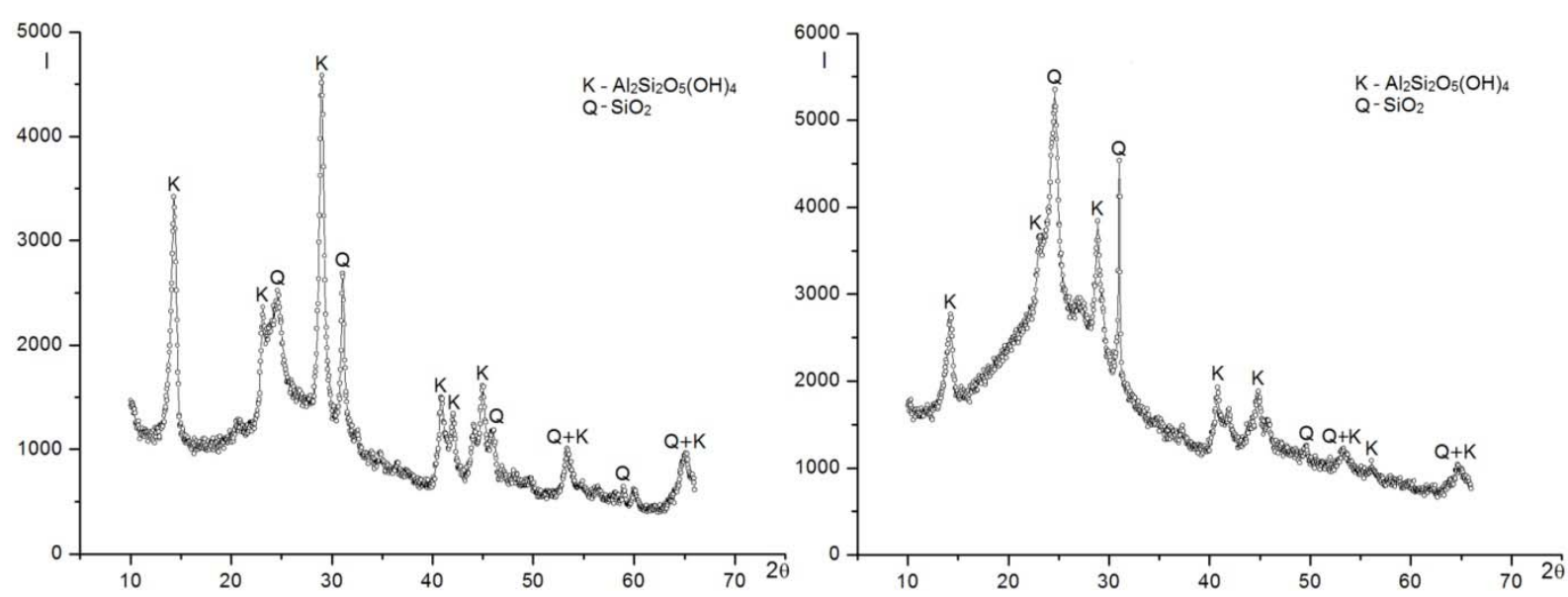

Fig. 2. Phase analysis (XRD) of Turów lignite: I (on the left) and II (on the right)
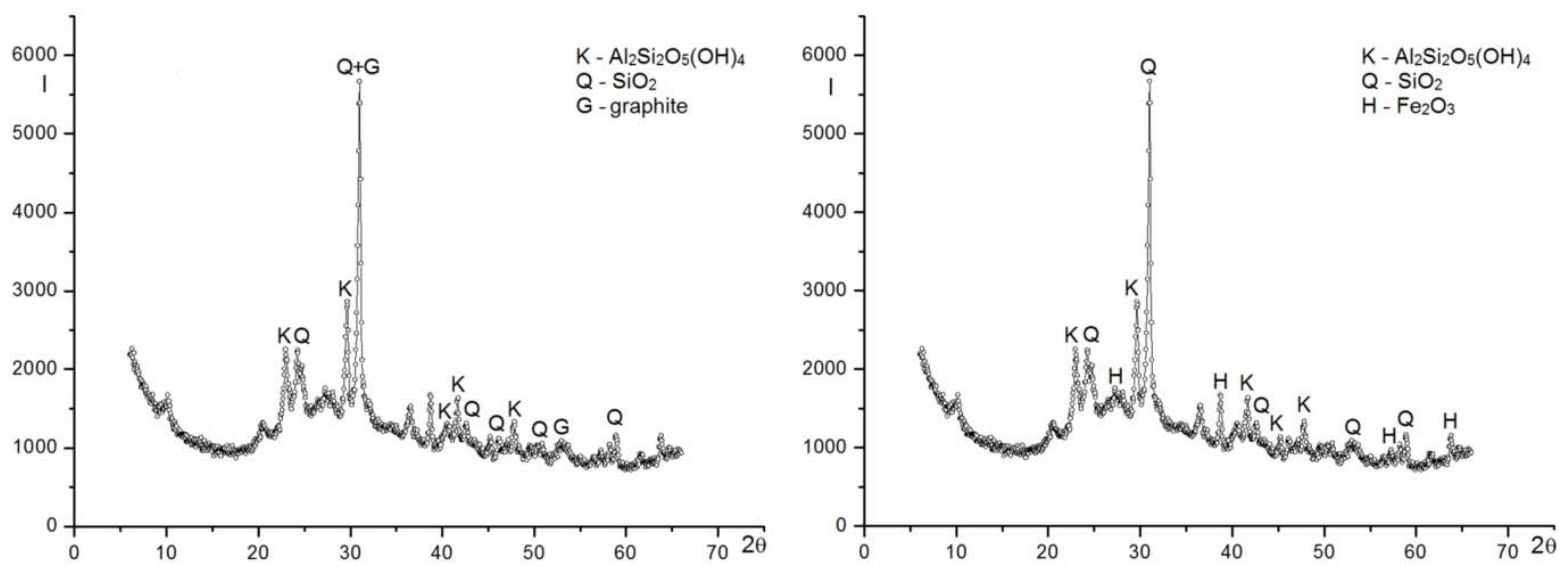

Fig. 3. Phase analysis (XRD) of Bolesław Śmiały bituminous coal (on the left) and its ash (on the right)

The samples of coals were dried, grinded and the fraction $<90 \mu \mathrm{m}$ was separated on the mesh. They were ashed according to Polish standard PN-EN 14775:2010 in the laboratory muffle oven at the temperature of $815^{\circ} \mathrm{C}$.

From bituminous coals Bolesław Śmiały coal was chosen as an additive. Only occasionally Wieczorek bituminous coal and Bełchatów lignite were used for comparison.

Table 5. Characteristics of selected coals and ash as possible additives

\begin{tabular}{|l|c|c|c|c|}
\hline \multicolumn{1}{|c|}{ Additive } & $\begin{array}{c}\text { Kaolinite in } \\
\text { ash, } \\
\% \text { mas. }\end{array}$ & $\begin{array}{c}\text { 作 } \\
\text { ratio }(\omega)\end{array}$ & $\begin{array}{c}\text { Sintering } \\
\text { temperature } \\
\text { of ash } \\
\text { (oxid. atm.) } \\
{ }^{\circ} \mathrm{C}\end{array}$ & $\begin{array}{c}\mathrm{Cl}^{\mathrm{d}}, \\
\% \text { mas. }\end{array}$ \\
\hline \multicolumn{5}{|c|}{ Lignite } \\
\hline Turów lignite I & 31 & 0.86 & 1170 & 0.05 \\
\hline Turów lignite II & 12.7 & 0.54 & N/A & LLD \\
\hline Bełchatów lignite & N/A & 0.81 & N/A & LLD \\
\hline \multicolumn{5}{|c|}{ Bituminous coals } \\
\hline Bolesław Śmiały coal & 7.2 & 0.69 & 1010 & 0.03 \\
\hline Bielszowice coal & 5.3 & 0.71 & 950 & 0.31 \\
\hline Wieczorek coal & 3.4 & 0.36 & 1260 & 0.28 \\
\hline
\end{tabular}

LLD - below the lower detection limit 


\section{RESULTS}

\subsection{The preliminary investigations}

\section{Chlorine release}

To assess the effectiveness of chlorine release from $\mathrm{KCl}$ by the selected coals and their ash, samples of $\mathrm{KCl}$ and an additive mixture were heated in the muffle furnace for $30 \mathrm{~min}$. The governing parameter was an additive mass ratio $A R$ being the percentage of additive ash $\left(m_{\text {add, ash }}\right)$ in the mixture with $\mathrm{KCl}$, i.e.:

$$
A R=m_{\text {add, ash }} /\left(m_{\text {add, ash }}+m_{\mathrm{KCl}}\right) \cdot 100 \%
$$

A few results of these investigations are presented in the graphical form in Figs. 4 and 5.

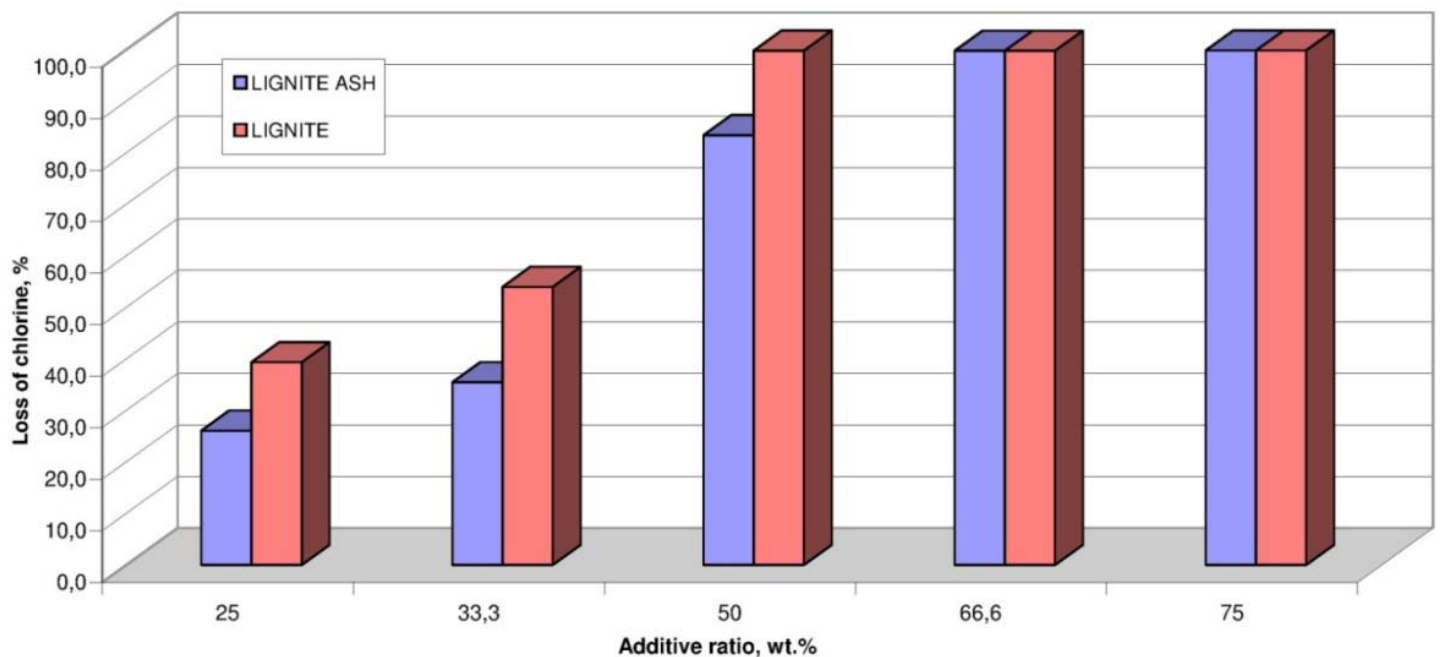

Fig. 4. The effectiveness of chlorine release during heating samples of $\mathrm{KCl}$ and Turów lignite $\mathrm{I}$ and $\mathrm{KCl}$ and Turów lignite I ash mixtures at the temperature of $1000^{\circ} \mathrm{C}$ vs. additive ratio

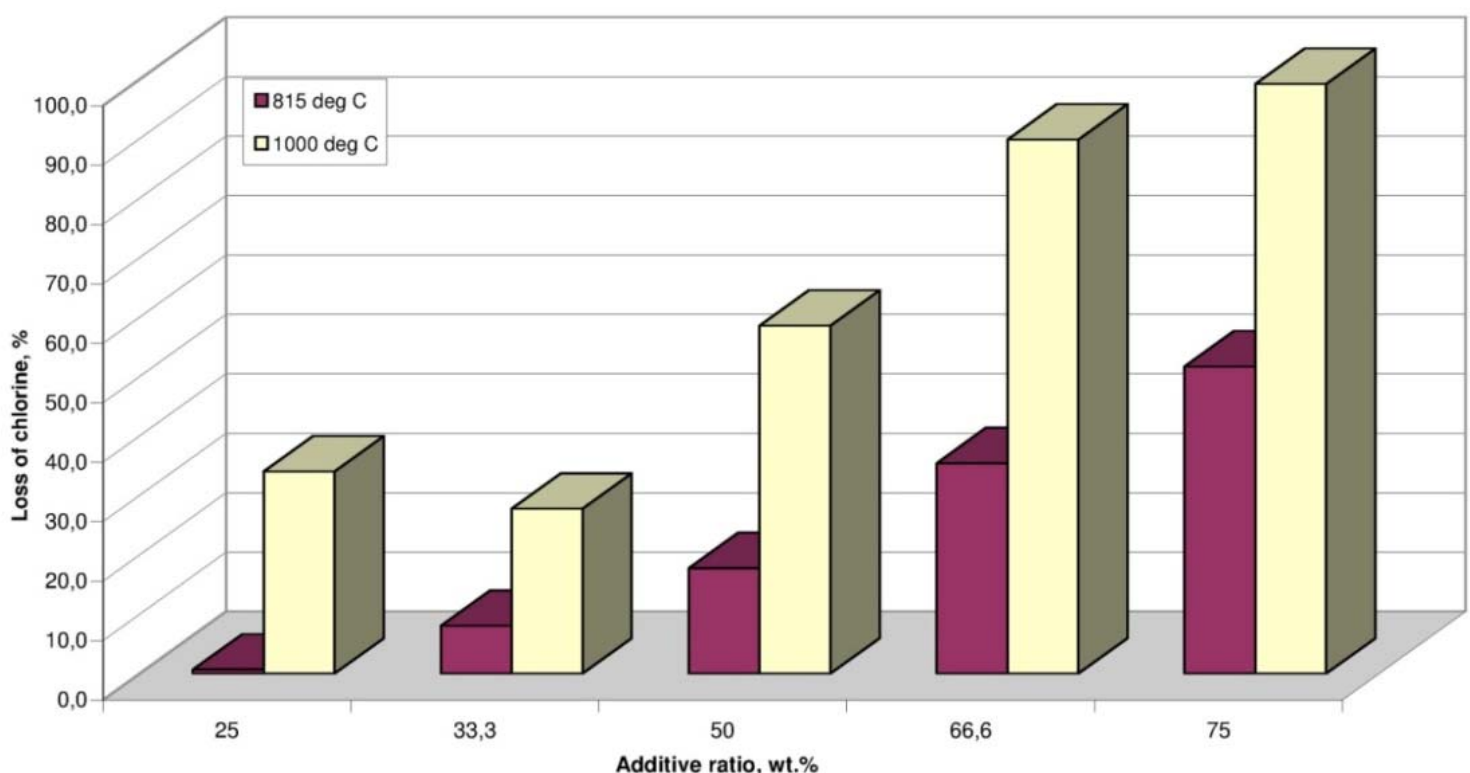

Fig. 5. The effectiveness of chlorine release during heating samples of $\mathrm{KCl}$ and Turów lignite II ash mixture at the temperature of 815 and $1000^{\circ} \mathrm{C}$ vs. the additive ratio 
Figure 5 shows that temperature has an important impact on chlorine loss from $\mathrm{KCl}$ in the reaction with ash. Table 6 presents collected results for the other coals. For the additive ratio $A R \geq 50 \%$ chlorine was almost completely released from the slag samples.

Table 6. Chlorine loss from samples of $\mathrm{KCl}$ and an additive mixture heated in the muffle furnace at the temperature of $1000^{\circ} \mathrm{C}$

\begin{tabular}{|c|c|c|c|c|c|c|}
\hline \multirow{2}{*}{ Additive } & \multicolumn{5}{|c|}{ Additive ratio $(A R), \%$ mass } \\
\cline { 3 - 7 } & 25 & 33 & 50 & 66 & 75 \\
\hline \multicolumn{7}{|c|}{ Chlorine loss $\left(\eta_{\mathrm{Cl}}\right)$ in the deposit after heating, \% } \\
\hline \multirow{2}{*}{ Turów } & Lignite I & 39.4 & 54 & 99.9 & 99.8 & 99.9 \\
\cline { 2 - 7 } & Lignite I ash & 26.1 & 35.5 & 83.5 & 99.8 & 99.9 \\
\hline \multirow{2}{*}{ Turów } & Lignite II & - & - & - & - & - \\
\cline { 2 - 7 } & Lignite II ash & 34 & 27.7 & 58.5 & 89.8 & 99.2 \\
\hline \multirow{2}{*}{$\begin{array}{c}\text { Bolesław } \\
\text { Śmiały }\end{array}$} & Coal & - & - & - & - & - \\
\cline { 2 - 7 } & Coal ash & 33.5 & 57.2 & 93.6 & 98.2 & 98.7 \\
\hline
\end{tabular}

Turów lignite I and its ash, and Bolesław Śmiały coal almost completely removed chlorine for $A R \geq$ $50 \%$. Perhaps due to higher kaolinite content the lignite Turów I appeared to be superior over Turów II (Tab. 5).

\section{Ash sintering}

To establish a rank of ash sintering, the biomass fuels were heated in the muffle furnace at the temperature of $1100^{\circ} \mathrm{C}$ for $30 \mathrm{~min}$ and slag samples were examined (Fig. 6). Cereal straw ash was almost completely melted, olive cake ash was strongly sintered, whereas rape straw ash was sintered and sunflower husk ash was only slightly sintered.

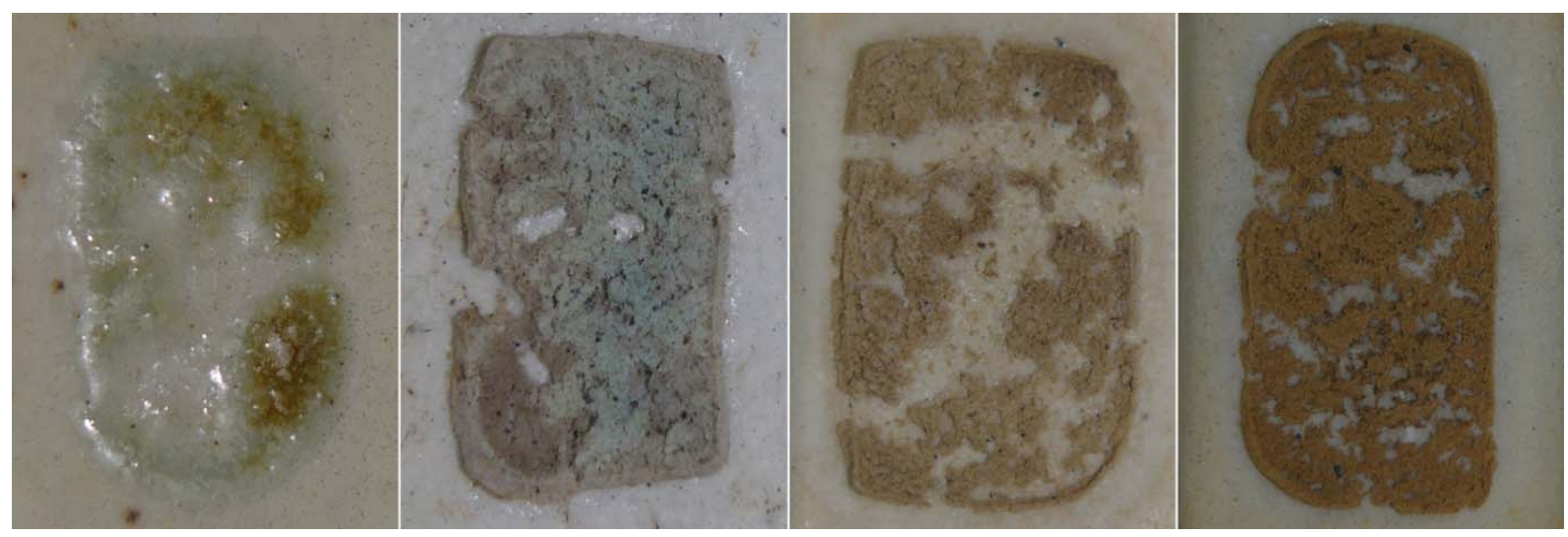

Fig. 6. Slag samples from biomass heating in the muffle furnace at the temperature of $1100^{\circ} \mathrm{C}$, from the left: cereal straw, olive cake, rape straw and sunflower husk

The effectiveness of additives for reducing biomass ash sintering was examined by heating samples of the mixture of grinded biomass and an additive in the muffle furnace at the temperature of $1000^{\circ} \mathrm{C}$ for $30 \mathrm{~min}$. Several experiments were conducted at the temperature of $1100^{\circ} \mathrm{C}$. The additive ratio $A R$ was approx. 50\%. The pictures of selected slag samples are shown in Figs. 7 and 8. 

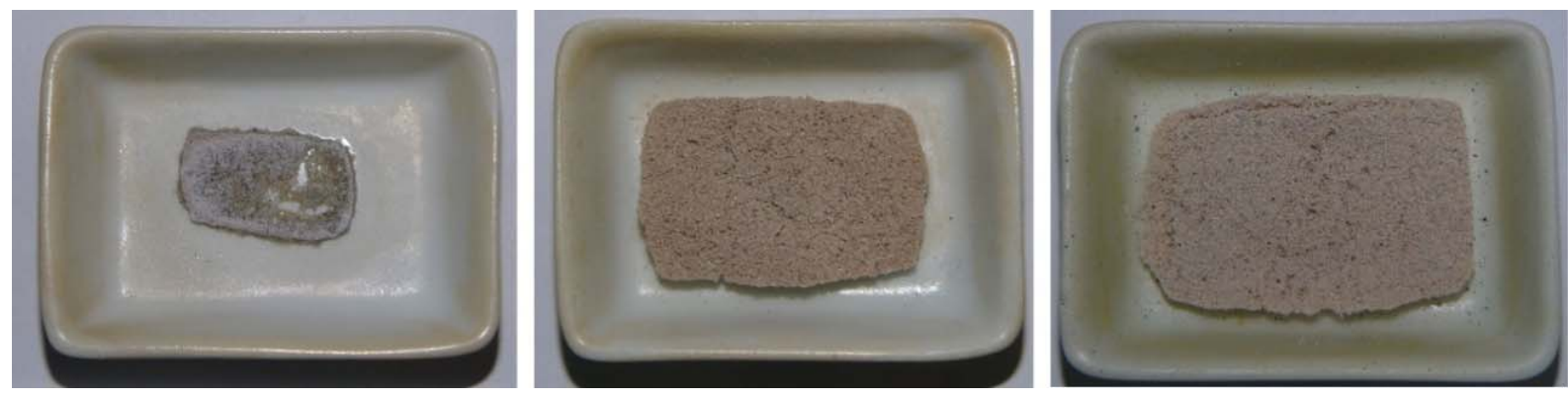

Fig. 7. Slag samples from cereal straw heated in the muffle furnace at the temperature of $1000^{\circ} \mathrm{C}$, from the left: without additive, with Bolesław Śmiały coal ash and Turów lignite I ash
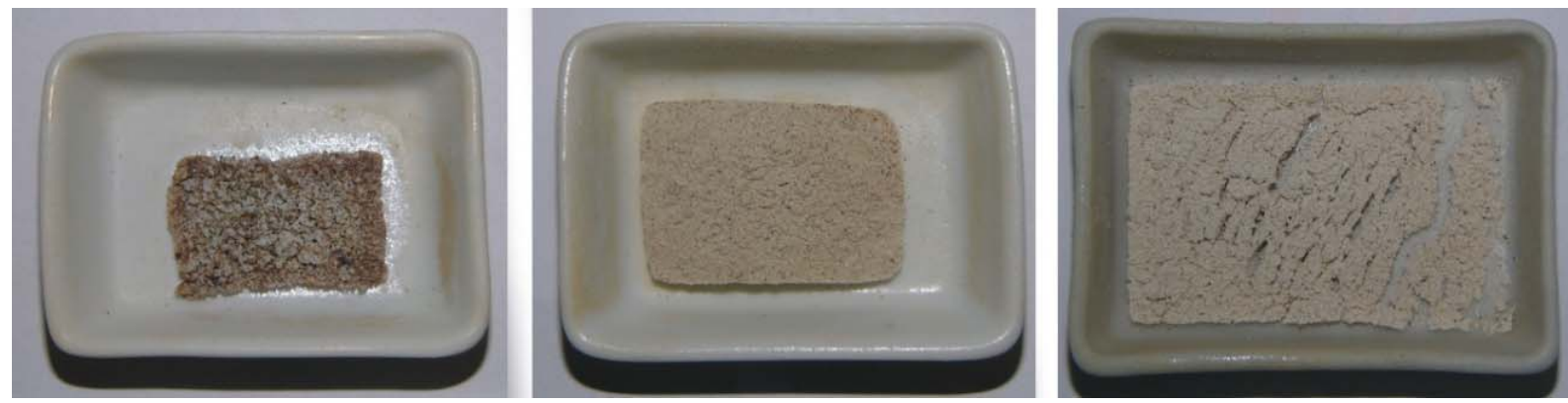

Fig. 8. Slag samples from olive cake heated in the muffle furnace at the temperature of $1000^{\circ} \mathrm{C}$, from the left: without additive, with Bolesław Śmiały coal ash and Turów lignite I ash

The sintering degree of the slag samples that were obtained at the temperature of 1000 and $1100^{\circ} \mathrm{C}$ was evaluated in the four-degree scale (Table 7).

Table 7. Sintering degree of the collected slag samples ${ }^{1}$ vs. used additives

\begin{tabular}{|l|c|c|c|c|c|}
\hline \multicolumn{1}{|c|}{ Fuel } & Additive & $\begin{array}{c}\text { Cereal } \\
\text { straw }\end{array}$ & Olive cake & $\begin{array}{c}\text { Rape } \\
\text { straw }\end{array}$ & $\begin{array}{c}\text { Sunflower } \\
\text { husk }\end{array}$ \\
\hline \multirow{2}{*}{ Biomass without additive } & - & $\begin{array}{c}3 \\
(3)^{2}\end{array}$ & $\begin{array}{c}3 \\
(3)^{2}\end{array}$ & $\begin{array}{c}2 \\
(3)^{2}\end{array}$ & $\begin{array}{c}1 \\
(2)^{2}\end{array}$ \\
\hline \multirow{2}{*}{ Coal mine } & \multicolumn{5}{|c|}{ Biomass with additive } \\
\hline \multirow{2}{*}{ Turów } & lignite I & - & - & - & - \\
\cline { 2 - 7 } & ash & 1 & 0 & 0 & 0 \\
\hline \multirow{2}{*}{ Turów } & lignite II & - & - & - & - \\
\cline { 2 - 7 } & ash & 1 & 0 & 0 & 0 \\
\hline \multirow{2}{*}{ Bolesław Śmiały } & coal & - & - & - & - \\
\cline { 2 - 7 } & ash & 1 & 1 & 0 & 0 \\
\hline \multirow{2}{*}{ Wieczorek } & coal & 32 & 22 & 2 & 12 \\
\cline { 2 - 7 } & ash & - & - & - & - \\
\hline
\end{tabular}

${ }^{1}$ sintering scale: 0 - loose, 1 - weakly sintered, 2 - sintered, 3 - strongly sintered;

${ }^{2}$ heating temperature $1100^{\circ} \mathrm{C}$

When heating temperature increased from 1000 to $1100^{\circ} \mathrm{C}$ the slag samples of rape straw and sunflower husk ash became one degree more sintered. The use of additives at the ratio $A R=50 \%$ considerably reduced ash sintering (1-2 degrees). Only Wieczorek coal had ambiguous or weak effect in spite of high sintering temperature of its ash (Tab. 5). This result may be due to low content of kaolinite in this coal. 


\subsection{Biomass-firing with additives in the down-fired furnace}

Mixtures of grinded biomass fuels and additives were fired in down-fired furnace (Fig.1) to examine the fuel-mixing effect on slagging tendency and chlorine release.

\section{Chlorine release}

The hydrochloride $\mathrm{HCl}$ content in flue gas was measured at the bottom of DFF in order to estimate the effect of additives on chlorine release during biomass fuel-firing. The additive ratio $A R$ was kept to $50 \%$.

Examples of the $[\mathrm{HCl}]$ course obtained during olive cake-firing are plotted in Fig. 9. When additives were used the content of $\mathrm{HCl}$ in flue gas was few times higher than for olive cake-firing individually (Tab. 8).

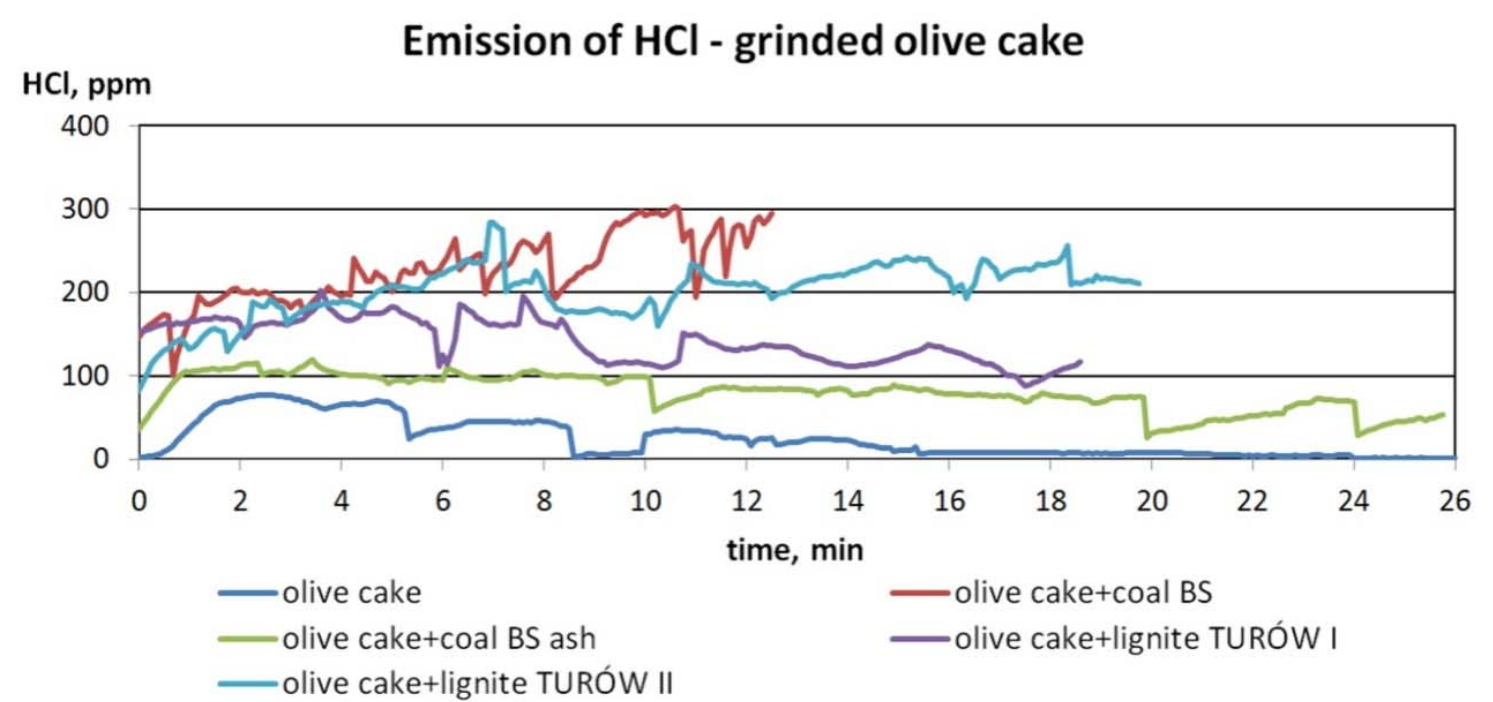

Fig. 9. The effect of additives on chlorine release into flue gas during olive cake-firing

Table 8. Mean values of hydrochloride content in flue gas during biomass-firing without and with additives in the DFF

\begin{tabular}{|l|c|c|c|c|}
\hline \multirow{2}{*}{ Biomass } & Cereal straw & Olive cake & Rape straw & $\begin{array}{c}\text { Sunflower } \\
\text { husk }\end{array}$ \\
\cline { 2 - 5 } & \multicolumn{4}{|c|}{ HCl, ppmv } \\
\hline Biomass without additives & 50 & 50 & 10 & 40 \\
\hline \multicolumn{1}{|c|}{ Additive } & \multicolumn{4}{|c|}{ Biomass with additives } \\
\hline Turów lignite I & 120 & 180 & 190 & 60 \\
\hline Turów lignite II & 210 & 210 & 300 & 140 \\
\hline Bolesław Śmiały coal & 170 & 240 & 300 & 60 \\
\hline Bolesław Śmiały coal ash & 175 & 100 & 450 & 75 \\
\hline
\end{tabular}

The obtained results show that an addition of the used coals caused 3 to 10 -fold increase of the $\mathrm{HCl}$ content in flue gas in contrast to the $\mathrm{HCl}$ level when biomass was individually fired. Lignite Turów I and Bolesław Śmiały coal were the most effective in chlorine liberation. 


\section{Ash sintering}

The slag samples were collected on the deposit probe during biomass fuels-firing individually and with the additives in the DFF (Fig. 1). Visual inspection and manual testing confirmed the positive effect of Turów lignite and Bolesław Śmiały coal addition (Figs. 10 and 11).
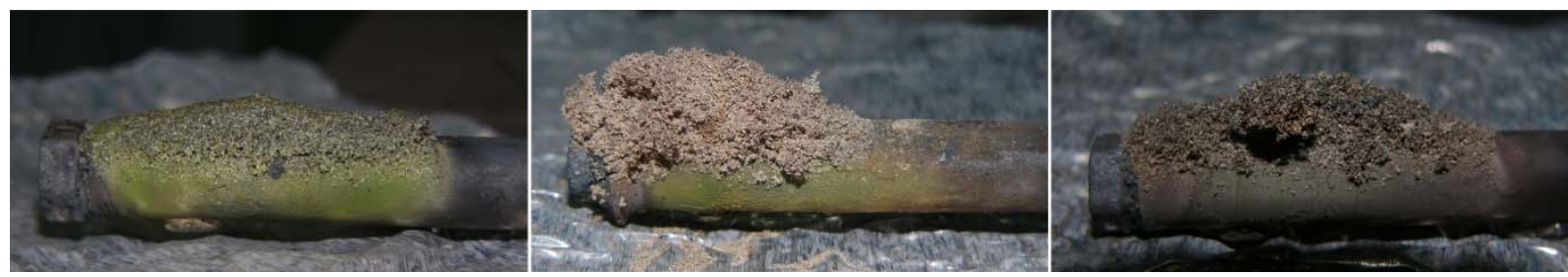

Fig. 10. Slag samples collected on the probe during biomass-firing, from the left: cereal straw, cereal straw with Turów lignite I ash and Bolesław Śmiały coal
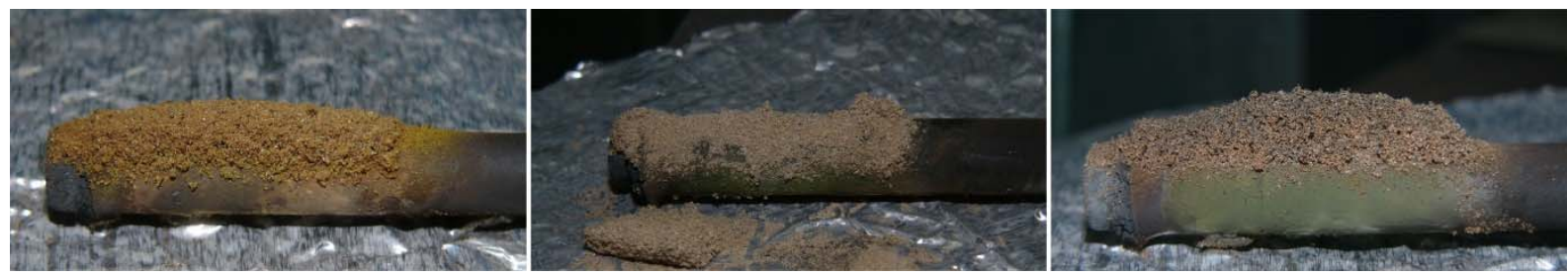

Fig. 11. Slag samples collected on the probe during biomass-firing, from the left: olive cake, olive cake with Turów lignite I ash and with Bolesław Śmiały coal

It was observed that the slag samples collected during individual biomass-firing were usually sintered and attached to the probe. When additives were used the deposit was loose and sometimes fell down from the probe. Evaluation of ash sintering for the other biomass fuels and the additives is shown in Table 9.

Table 9. Effect of additives on ash sintering ${ }^{1}$

\begin{tabular}{|l|c|c|c|c|c|}
\hline \multicolumn{1}{|c|}{ Fuel } & Additive & $\begin{array}{c}\text { Cereal } \\
\text { straw }\end{array}$ & $\begin{array}{c}\text { Olive } \\
\text { cake }\end{array}$ & $\begin{array}{c}\text { Rape } \\
\text { straw }\end{array}$ & $\begin{array}{c}\text { Sunflower } \\
\text { husk }\end{array}$ \\
\hline Biomass without additive & --- & 3 & 2 & 1 & 0 \\
\hline Coal mine & \multicolumn{5}{|c|}{ Biomass with additive } \\
\hline \multirow{2}{*}{ Turów } & lignite I & 1 & 2 & 1 & 0 \\
\cline { 2 - 7 } & ash & 1 & 2 & 1 & 0 \\
\hline \multirow{2}{*}{ Turów } & lignite II & 1 & 1 & 0 & 0 \\
\cline { 2 - 7 } & ash & - & - & - & - \\
\hline \multirow{2}{*}{ Bolesław Śmiały } & coal & 1 & 0 & 1 & 0 \\
\cline { 2 - 7 } & ash & 1 & 1 & 0 & 0 \\
\hline
\end{tabular}

${ }^{1}$ sintering scale SD: 0 - loose, 1 - weekly sintered, 2 - sintered, 3 - strongly sintered

The most intensive ash sintering was observed during cereal straw-firing $(S D=3)$. The addition of Turów lignite or Bolesław Śmiały coal made the slag sample only weakly sintered $(S D=1)$. The same effect was observed when ash was added. The deposits collected from olive cake-firing were only sintered $(S D=2)$, and after lignite Turów II or Bolesław Śmiały coal was added sintering degree 
declined $(S D=1)$. It was surprising that Turów lignite I was less effective than Turów II lignite and Bolesław Śmiały coal in this case. Slag samples from rape straw-firing were only weakly sintered, hence additives did not clearly change it. Sunflower husk ash appeared to be completely resistant to sintering $(S D=0)$.

\section{Crystalline analysis of slag samples}

Crystalline components of selected slag samples were identified using X-ray powder diffraction technique (XRD). Figures 12 and 13 show X-ray spectra of slag samples collected during firing of the cereal straw that was mixed with Turów lignite I ash and Bolesław Śmiały coal in the DFF. The additive mass ratio $A R$ was $50 \%$.

In the slag samples relatively weak lines of kalsilite $(\mathrm{K})$ were discovered. Kalsilite is a potassium aluminosilicate of the melting temperature of about $1600^{\circ} \mathrm{C}$ (Fernandez Llorente et al., 2008). Strong lines of silica and mullite were additionally found. The shape of the graphs (lift - off within the range of $30-40^{\circ}$ ) indicates that the deposit structure was amorphous (glassy) to a large extend, which means that the residence time in the DFF was too short to develop all crystalline components.

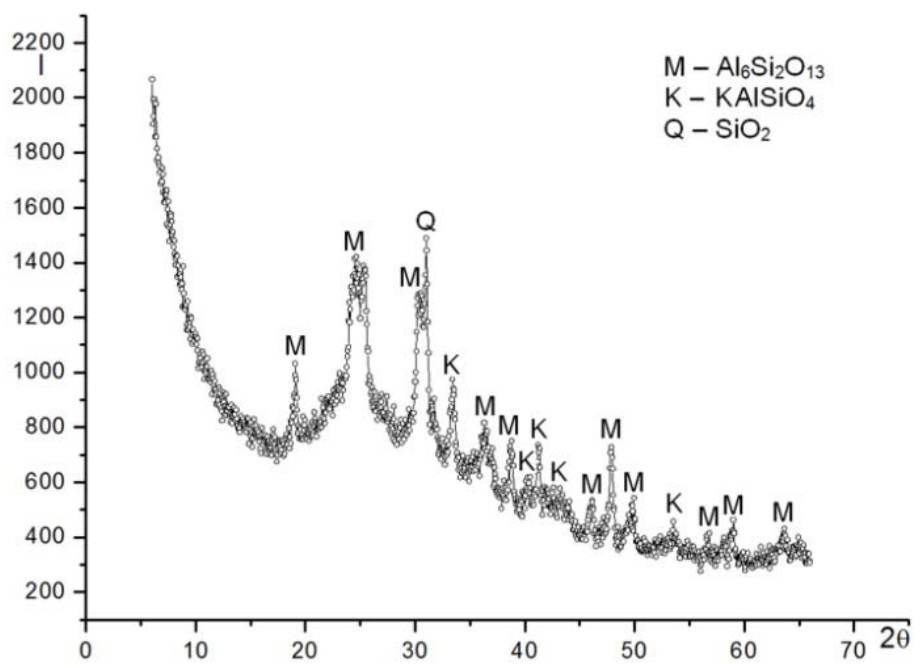

Fig. 12. X-ray spectra of the slag sample collected during firing cereal straw mixed with Turów lignite I ash in the DFF

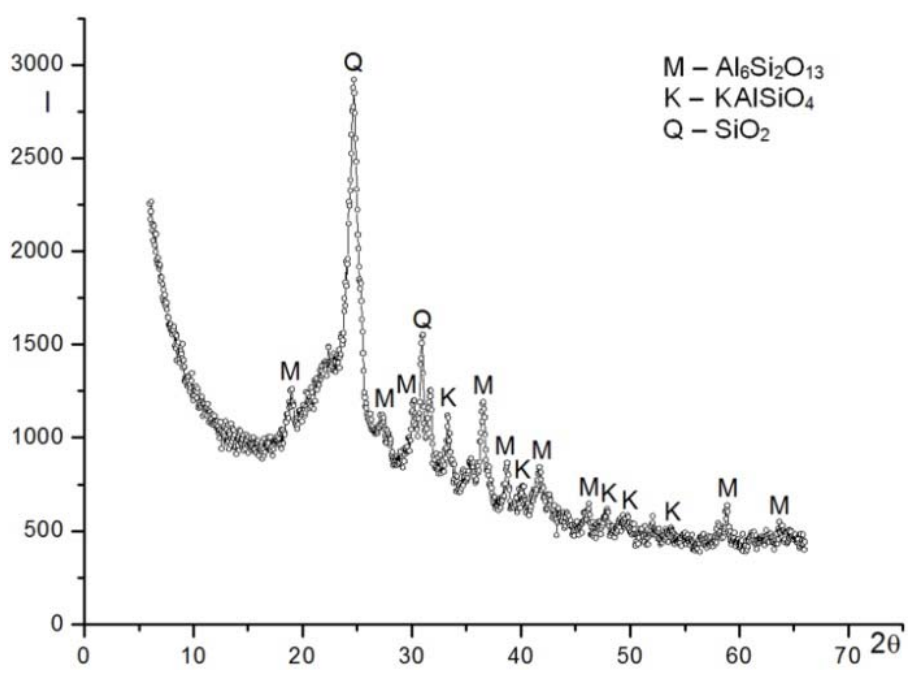

Fig. 13. X-ray spectra of the slag sample collected during firing cereal straw mixed with Bolesław Śmiały coal in the DFF 


\section{DISCUSSION}

The selected coals (Turów lignite I and Bolesław Śmiały bituminous coal) and their ash appear to be promising candidates for anti-sintering additives during biomass-firing in boilers. The conducted experiments showed a reduced degree of slagging and effective chlorine liberation. The observed effects were similar to those noticed earlier when minerals of the aluminosilicates type were used as anti-corrosion additives (Hardy et al., 2013).

The mechanism of anti-sintering kaolinite $\left(\mathrm{Al}_{2} \mathrm{Si}_{2} \mathrm{O}_{5}(\mathrm{OH})_{4}\right)$ influence could be illustrated by the overall reaction of kaolinite with $\mathrm{KCl}$ (Aho, 2001):

$$
\mathrm{Al}_{2} \mathrm{SiO}_{5}(\mathrm{OH})_{4}+2 \mathrm{KCl}+2 \mathrm{SiO}_{2} \rightarrow 2 \mathrm{KAlSi}_{2} \mathrm{O}_{6}+2 \mathrm{H}_{2} \mathrm{O}+2 \mathrm{HCl}
$$

in which kalsilite $\left(\mathrm{KAlSiO}_{4}\right)$ is formed.

In fact, the process is complex and includes several stages (Tran et al., 2005):

- kaolinite de-hydroxylation and meta-kaolinite $\left(\mathrm{Al}_{2} \mathrm{O}_{3} \cdot 2 \mathrm{SiO}_{2}\right)$ formation,

- chemical adsorption of gaseous $\mathrm{KCl}$ on the meta-kaolinite surface $\mathrm{S}$

$$
2 \mathrm{KClg}+\mathrm{S}=\mathrm{S} \cdot 2 \mathrm{KCl}
$$

- reaction of $\mathrm{KCl}$ with water and $\mathrm{HCl}$ release

$$
\mathrm{S} \cdot 2 \mathrm{KCl}+\mathrm{H}_{2} \mathrm{O}_{(\mathrm{g})}=\mathrm{K}_{2} \mathrm{O} \cdot \mathrm{S}+2 \mathrm{HCl}
$$

- potassium aluminosilicate formation

$$
\mathrm{K}_{2} \mathrm{O} \cdot \mathrm{S}=\mathrm{K}_{2} \mathrm{O} \cdot \mathrm{Al}_{2} \mathrm{O}_{3} \cdot 2 \mathrm{SiO}_{2}=2 \mathrm{KAlSiO}_{4}
$$

The advantage of this process is the capture of potassium from flue gas and binding high-temperature melting aluminosilicates, like kalsilite. However, formation of potassium aluminosilicates in this complex process requires an appropriate residence time in the combustion chamber.

When the $\mathrm{KCl}$ and haloysite mixture was heated in the laboratory oven for $30 \mathrm{~min}$. a predominant crystalline component found in the slag sample was kalsilite (Hardy, 2013). In this case the residence time at the temperature range of $1100-1150^{\circ} \mathrm{C}$ in the DFF was only $1-2 \mathrm{~s}$, hence the kalsilite lines were relatively weak (Fig. 12 and 13).

Chlorine release from $\mathrm{KCl}$ in the form of $\mathrm{HCl}$ has a positive effect because hydrogen chloride is less corrosive at the boiler furnace than molecular chlorine $\mathrm{Cl}_{2}$ (Frandsen and van Lith, 2009).

\section{CONCLUSIONS}

The conducted lab-scale experiments of fuel-mixing influence on biomass-firing induced slagging tendency and chlorine content in ash, lead to the following conclusions:

- Fuel-mixing could considerably reduce slagging intensity and chlorine content in slag during biomass-firing in boilers.

- Turów lignite I and Bolesław Śmiały bituminous coal were found to be promising candidates for anti-sintering additives in biomass-firing.

- Effectiveness of chlorine release due to reaction between coal ash and $\mathrm{KCl}$ depends on the temperature, i.e. at least $1000 \mathrm{C}$ is required for almost entire removal of chlorine.

- Kaolinite content in coal was seen as the major factor in slagging abatement and chlorine release from slag in biomass-firing by fuel-mixing. 
The results presented in the paper were obtained from the research work financed by EDF Polska in the framework of P-9/2012 project "Additives reducing negative effects of biomass co-firing at a high rate".

\section{REFERENCES}

Aho M., 2001. Reduction of chlorine deposition in FB boilers with aluminium-containing additives. Fuel, 80, 1943-1951. DOI: 10.1016/S0016-2361(01)00049-7.

Chudek M., Hycnal J., Janiczek S., Plewa F., 1999. Lignite. Silesian University of Technology, Gliwice (in Polish).

Fernández Llorentea M.J., Díaz Arocas P., Gutiérrez Nebot L., Carrasco García J.E., 2008. The effect of the addition of chemical materials on the sintering of biomass ash. Fuel, 87, 2651-2658. DOI: $\overline{10.1016 / j . f u e l .2008 .02 .019 .}$

Frandsen F., J. van Lith S., 2009. Detailed investigation of Cl-corrosion initiated by deposits formed in biomass biomass-fired boilers, FORSKEL-5820, Final Report No.0905.

Hardy T., Kordylewski W., Mościcki K., 2013. Aluminosilicate sorbents for control of $\mathrm{KCl}$ vapors in biomass combustion gases. J. Power Technologies, 93, 37-43.

Hardy, T., 2001. Laboratory set-up for investigations of deposits of biomass-firing with selected additives in the drop-tube furnace, In: Wejkowski R., Janda T. (Eds.), R\&D Project Report ECOALBOILER Investigations for improving operational efficiency, environmental performance and reduction in maintenance cost of boilers, EDF Polska, CUW, Kraków.

Kassman H., Wollner L., Berg M., 2013.The ChlorOut concept - a method to reduce alkali-related problems during combustion. VGB PowerTech, 6, 62-67.

Kordylewski W., Mościcki K., 2012. Additives reducing negative effects of biomass co-firing at a high rate. Report no: 47/2012, P-9/2012 PROJECT. Wrocław University of Technology, Wrocław.

Lee S.H., Themelis N.J., Castaldi M.J., 2007. High-temperature corrosion in waste-to-energy boilers. J. Thermal Spray Technology, 16, 1-7. DOI: 10.1007/s11666-006-9005-4.

Montgomery M., Karlsson A., Larsen O.H., 2002. Field test corrosion experiments in Denmark with biomass fuels. Part I: Straw firing. Mater. Corros., 53, 121-131. DOI: 10.1002/1521-4176(200202)53:2<121::AIDMACO121>3.0.CO;2-R.

Montgomery M., Jensen S. A., Borg U., Biede O., Vilhelmsen T., 2011. Experiences with high temperature corrosion at straw-firing power plants in Denmark. Mater. Corros., 62, 593-605. DOI: 10.1002/maco.201005856.

Polish Hard Coal, Catalogue, 2001. PARGWK, Katowice.

Steenari B.-M ., Lindqvis O., 1998. High-temperature reactions of straw ash and the anti-sintering additives kaolin and dolomite. Biomass Bioenergy, 14, 67-76. DOI: 10.1016/S0961-9534(97)00035-4.

Steenari B.-M., Lundberg A., Peterson H., Wasilewska-Bien M., Andersson D., 2009. Investigation of ash. sintering during combustion of agriculture residues and the effect of additives. Energy Fuels, $\overline{23}, \overline{5655} \overline{5662}$.

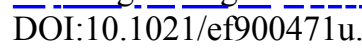

Theis M., Skrifvars B.J., Hupa M., Tran H., 2006. Fouling tendency of ash resulting from burning mixtures of biofuels. Part 1: Deposition rates. Fuel, 85, 1125-1130. DOI: 10.1016/j.fuel.2005.10.010.

Tran K. Q., Iisa K., Steenari B-M, Lindqvist O., 2005. A kinetic study of gaseous alkali capture by kaolin in the fixed bed reactor equipped with an alkali detector. Fuel, 84, $169-175$. DOI: $10.1016 / \bar{j}$.fuel.2004.08.019.

Uusitalo M.A., Vuoristo P.M.J., Mantyla T.A., 2002. Elevated temperature erosion-corrosion of thermal sprayed coatings in chlorine containing environments. Wear, 252, 586-594. DOI: 10.1016/S0043-1648(02)00014-5. 